\title{
KARATERISTIK YOGURT EDAMAME HASIL FERMENTASI KULTUR CAMPURAN BAKTERI ASAM LAKTAT KOMERSIAL SEBAGAI PANGAN FUNGSIONAL BERBASIS BIJI-BIJIAN
}

\author{
CHARACTERISTIC of YOGURT EDAMAME RESULT by \\ FERMENTATION of MIXED LACTIC ACID BACTERIA as \\ FUNCTIONAL FOOD From GRAIN
}

\author{
${ }^{1}$ Nita Maria Rosiana, ${ }^{2}$ Dahlia Indah Amareta \\ ${ }^{1,2}$ Program Studi Gizi Klinik Jurusan Kesehatan Politeknik Negeri Jember \\ Jalan Mastrip Kotak Pos 164 Jember \\ nita.maria.r@gmail.com
}

\begin{abstract}
Abstrak
Penelitian ini bertujuan untuk mengetahui karakteristik yogurt edamame hasil fermentasi kultur campuran dengan kajian jumlah kultur campuran dan waktu fermentasi. Rancangan penelitian menggunakan Rancangan Acak Kelompok (RAK) dengan dua faktor yaitu jumlah kultur campuran dan waktu fermentasi. Jumlah kultur campuran yang digunakan adalah 3\%, 5\% dan 7\% sedangkan waktu fermentasi adalah 6 jam, 12 jam dan 24 jam dengan tiga kali ulangan. Analisa yang dilakukan pada produk yogurt edamame adalah $\mathrm{pH}$, konsistensi dan organoleptik. Perlakuan terbaik selanjutnya dianalisa aktivitas antioksidan. Data yang diperoleh dianalisa menggunakan ANOVA dengan uji lanjut Duncan's Multiple Range Test dengan bantuan software SPSS. Penentuan perlakuan terbaik dengan metode De Garmo. Hasil penelitian menunjukkan perlakuan terbaik adalah yogurt dengan jumlah kultur 7\% dengan waktu fermentasi 24 jam. Yogurt ini memiliki karakteristik pH 4,39, konsistensi 3,56 cm, kesukaan warna, aroma, rasa dan tekstur netral. Sedangkan pada mutu hedonic warna agak hijau, aroma dan rasa asam, tekstur kental. Aktivitas antioksidan yogurt edamame adalah $19,18 \%$
\end{abstract}

Kata kunci : edamame, pangan fungsional, yogurt

\begin{abstract}
This research aims to investigate the characteristics of edamame yogurt that fermented with mixed starter with an assessment of the number of mixed starter and fermentation time. The research used randomized block design with two factors, the number of mixed starter and fermentation time with 3 replications. Number of mixed cultures used were 3\%, 5\% and 7\%, while the fermentation time were 6 hours, 12 hours and 24 hours. Analysis performed on edamame yogurt products were $\mathrm{pH}$, consistency and organoleptic. The best treatment was further analyzed antioxidant activity. Data were analyzed using analysis of variance followed by Duncan's Multiple Range Test with SPSS. The best treatment choosen by De Garmo. Based on the research, the best treatment was the yogurt with a number of cultures $7 \%$ with 24 hours fermentation period. Yogurt has characteristics of $\mathrm{pH} 4.39,3.56 \mathrm{~cm}$ consistency, color, aroma, taste and texture was neutral. While the hedonic quality rather green color, aroma and taste was sour, creamy texture. The antioxidant activity of yogurt edamame is $19.18 \%$
\end{abstract}

Key words : edamame, fungsional food, yogurt

\section{PENDAHULUAN}

Provinsi Jawa Timur merupakan produsen kedelai terbesar di Indonesia. Produksi kedelai sekitar $42 \%$ produksi kedelai nasional. Kabupaten Jember, pada tahun 2013 produksi kedelai mencapai 27.732 ton dengan kebutuhan konsumsi 25.473 ton sehingga mengalami surplus 2.259 ton. Kedelai jenis edamame memiliki keunggulan kandungan protein tinggi dan lengkap, di mana kandungan protein edamame mencapai $36 \%$, lebih tinggi dibanding kedelai lain. Edamame juga mengandung sembilan asam amino esensial yang diperlukan tubuh. Edamame juga tidak mengandung kolesterol dan sedikit lemak jenuh, plus kaya serat, vitamin $\mathrm{C}$ dan B, serta kalsium, zat besi atau magnesium, dan asam folat. Bahkan menurut Samruan et al (2012), kedelai edamame mengandung komponen fitokimia yaitu isoflavon $(0,1-3 \%)$, sterol $(0,23-0,46 \%)$ dan saponin $(0,12$ $6,16 \%)$ yang dapat menurunkan resiko penyakit 
stroke, jantung, hipertensi, diabetes dan hiperkolesterol.

Pada umumnya kedelai edamame harus segera diolah menjadi produk beku dan siap santap

atau frozen ready to eat. Edamame harus diolah secara langsung pada pada hari itu juga setelah panen. Hasil olahan edamame antara lain miso. Namun miso edamame belum menghasilkan miso yang lebih baik dari komersial. Sedangkan susu edamame (Wahyuhapsari dan Wardani, 2013). Oalahan edamame lain adalah dan susu edamame yang mengandung senyawa bioaktif yaitu total fenol sebesar 0,023 mgGAE/g. Susu edamame ini mampu menurunkan resiko hiperkolesterolemik sehingga dapat mencegah dan menurunkan resiko berbagai macam penyakit tidak menular terutama penyakit jantung koroner, penyebab kematian nomor satu di dunia (Fitriyana, 2014). Oleh karena itu diperlukan pengembangan produk olahan edamame yang disukai oleh masyarakat yaitu yogurt.

Mutu dan citarasa yogurt dipengaruhi oleh jenis mikroorganisme yang digunakan Setiap jenis bakteri mempunyai kemampuan memecah substrat yang berbeda-beda sehingga menghasilkan metabolit yang berbeda pula. Selama proses fermentasi akan terjadi perubahan pada protein, lemak, karbohidrat, dan juga bahan organik lain melalui enzym yang dikeluarkan oleh mikroorganisme tersebut (Zakaria, 2008). Jenis mikroorganisme yang digunakan adalah Lactobacillus acidophilus, Bifidobacterium longum, Lactobacillus bulgaricus dan Streptococcus thermophillus. Penggunaan mikroorganisme tersebut pada yogurt susu skim yang ditambahkan sari buah belimbing dapat menurunkan $\mathrm{pH}$ dan memiliki citarasa cenderung asam yang agak disukai panelis (Jannah dkk, 2014). Sedangkan menurut Fatmawati dkk (2013) penggunaan Lactobacillus bulgaricus dan Streptococcus thermophillus pada yogurt susu UHT dapat menghasilkan yogurt kualitas baik. Semakin tingi jumlah mikroorganisme yang digunakan, maka proses fermentasi berlangsung lebih cepat karena subtrat lebih banyak yang digunakan sehingga berpengaruh terhadap mutu yogurt.

Waktu fermentasi juga berpengaruh terhadap mutu dan citarasa selama proses fermentasi. Semakin lama proses fermentasi, maka semakin tinggi jumlah metabolit yang dihasilkan. Kartikasari dan Nisa (2014) menyebutkan bahwa semakin lama proses fermentasi yogurt susu sapi buah sirsak dengan kultur Lactobacillus, Streptococcus. thermophillus, L. acidophilus dan Bifidobacterium dapat menurunkan $\mathrm{pH}$, meningkatkan total asam dan antioksidan yogurt.
Salah satu hasil metabolit pada yogurt adalah peptide bioaktif yang memiliki sifat antioksidan. Selain itu fenol dan isoflavon pada edamame juga merupakan jenis antioksidan yang terdapat pada

yogurt edamame. Antioksidan merupakan suatu senyawa yang berfungsi untuk melindungi sel dari efek berbahaya radikal bebas oksigen yang berasal dari metabolisme tubuh maupun faktor eksternal lainnya. Senyawa antioksidan memiliki peran yang sangat penting dalam kesehatan. Berbagai bukti ilmiah menunjukkan bahwa senyawa antioksidan mengurangi resiko terhadap penyakit kronis seperti kanker dan penyakit jantung koroner (Amrun et al., 2007). Keberadaan antioksidan pada yogurt edamame menjadikan yogurt ini menjadi salah satu sumber pangan fungsional. Berdasarkan latar belakang yang telah diuraikan tersebut, maka dilakukan penelitian ini dengan tujuan mengetahui karakteristik yogurt edamame hasil fermentasi kultur campuran dengan kajian jumlah kultur campuran dan waktu fermentasi.

\section{METODOLOGI}

Bahan utama pembuatan yogurt adalah edamame mentah dari Koperasi Mitratani Jember. Kultur didapat dari "Biokul plain" dan menggunakan gula "Gulaku”.

Penelitian dilakukan di Laboratorium Biosain Politeknik Negeri Jember. Analisa kimia terdiri dari pH dan konsistensi. Selanjutnya dilakukan uji kesukaan dan uji mutu hedonik menggunakan 25 panelis. Selanjutnya perlakuan terbaik dilakukan analisa aktivitas antioksidan.

Pembuatan sari edamame dengan cara memisahkan biji edamame dengan kulitnya, kemudian dicuci dan ditiriskan. Selanjutnya dilakukan penimbangan kemudian direbus selama 3-5 menit. Kemudian penghancuran biji edamame dengan perbandingan edamame $=3: 1$. Selanjutnya sari edamame disaring. (Modifikasi Fitriyana, 2013).

Pembuatan yogurt edamame mengacu pada modifikasi Prasetyo (2010). Pasteurisasi sari edamame pada suhu $80-85^{\circ} \mathrm{C}$ selama 30 menit, tambahkan gula $4 \%$ dari volume susu. Turunkan suhu hingga mencapai $45^{\circ} \mathrm{C}$, Tambahkan kultur yoghurt sesuai dengan perlakuan yaitu $3 \%, 5 \%$ dan $7 \%$ dari volume susu dan simpan dalam suhu ruangan selama 6, 12 dan 24 jam

Rancangan percobaan yang dilakukan adalah Rancangan Acak Kelompok dengan dua factor. Faktor pertama adalah jumlah kultur yaitu 3\%, 5\% dan $7 \%$. Sedangkan factor kedua adalah waktu fermentasi yaitu 6 jam, 12 jam dan 24 jam. Analisa data menggunakan ANOVA. Jika berbeda nyata maka dilanjutkan dengan uji Duncan. 
Nita Maria Rosiana, Dahlia Indah Amareta, Karakteristik Yogurt Edamame Hasil Fermentasi Kultur Campuran Bakteri Asam Laktat Komersial Sebagai Pangan Fungsional Berbasis Biji-Bijian

Analisa pada produk yogurt adalah $\mathrm{pH}$, konsistensi menggunakan konsistometer dan organolpetik. Uji organoleptic menggunakan 25 panelis agak terlatih. Uji oragnoleptik meliputi uji kesukaan dan uji mutu hedonic. Skor uji kesukaan warna, aroma, rasa dan tekstur adalah 1 : sangat tidak suka, 2 : tidak suka, 3 : agak suka, 4 : netral, 5 : agak suka, 6 : sangat suka. Sedangkan skor uji mutu hedonic disajikan pada Tabel 1.

Tabel 1. Skor Uji Mutu Organoleptik

\begin{tabular}{|l|l|l|}
\hline \multicolumn{1}{|c|}{ Parameter } & \multicolumn{1}{|c|}{ Kriteria } & \multicolumn{1}{c|}{ Skor } \\
\hline Warna & Sangat hijau & 5 \\
\cline { 2 - 3 } & Hijau & 4 \\
\cline { 2 - 3 } & Netral & 3 \\
\cline { 2 - 3 } & Agak hijau & 2 \\
\cline { 2 - 3 } & Puth & 1 \\
\hline Aroma & Amat sangat asam & 5 \\
\cline { 2 - 3 } & Sangat asam & 4 \\
\cline { 2 - 3 } & Asam & 3 \\
\cline { 2 - 3 } & Agak asam & 2 \\
\cline { 2 - 3 } & Tidak asam & 1 \\
\hline Rasa & Amat sangat asam & 5 \\
\cline { 2 - 3 } & Sangat asam & 4 \\
\cline { 2 - 3 } & Asam & 3 \\
\cline { 2 - 3 } & Agak asam & 2 \\
\cline { 2 - 3 } & Tidak asam & 1 \\
\hline Tekstur & Sangat kental & 5 \\
\cline { 2 - 3 } & Agak kental & 4 \\
\cline { 2 - 3 } & Kental & 3 \\
\cline { 2 - 3 } & Tidak kental & 2 \\
\cline { 2 - 3 } & Sangat \\
kental/encer & 1 \\
\hline
\end{tabular}

\section{HASIL DAN PEMBAHASAN pH}

Hasil penelitian menunjukkan nilai $\mathrm{pH}$ pada yogurt edamame adalah berkisar antara 4,395,38 (Tabel 2).

Hasil analisa ragam menunjukkan menunjukkan bahwa semakin tinggi jumlah starter dan semakin lama waktu fermentasi maka berpengaruh nyata $(\mathrm{P}<0,05)$ terhadap $\mathrm{pH}$ yogurt edamame. $\mathrm{pH}$ terendah 4,39 yaitu pada perlakuan jumlah starter $7 \%$ dan waktu fermentasi 24 jam. Persyaratan $\mathrm{pH}$ pada produk yogurt yaitu pada kisaran 4-4,5 (Kartikasari dan Nisa, 2014). Bakteri asam laktat yang digunakan akan menghidrolisis komponen pada sari edamame menghasilkan metabolit berupa asam yang dapat menurunkan $\mathrm{pH}$ produk. Pada waktu fermentasi 6 jam belum terjadi proses fermentasi yang sempurna sehingga $\mathrm{pH}$ yang dihasilkan cukup tinggi yaitu pada rentang 5,38-5,44. Asam laktat yang terbentuk selama proses fermentasi akan disekresikan keluar sel sehingga terakumulasi dalam media fermentasi. Oleh karena itu semakin lama waktu fermentasi, maka jumlah total asam laktat yang terakumulasi semakin meningkat dan menurunkan $\mathrm{pH}$.
Sedangkan menurut Prasetyo (2010), semakin tinggi jumlah kultur yang digunakan maka semakin tinggi peningkatan aktivitas dan perkembangan mikroba sehingga dapat meningkatkan laju perombakan laktosa menjadi asam laktat yang dapat menurunkan nilai $\mathrm{pH}$.

Tabel 2. Hasil Analisa pH dan Konsistensi

\begin{tabular}{|c|c|c|c|}
\hline \multicolumn{2}{|c|}{ Perlakuan } & \multirow{2}{*}{ pH } & \multirow{2}{*}{$\begin{array}{c}\text { Konsistensi } \\
(\mathbf{c m})\end{array}$} \\
\hline $\begin{array}{c}\text { Jumlah } \\
\text { starter }\end{array}$ & $\begin{array}{c}\text { Waktu } \\
\text { fermentasi } \\
(\mathbf{j a m})\end{array}$ & & \\
\hline \multirow{3}{*}{3} & 6 & $5,38^{\mathrm{c}}$ & $4,07^{\mathrm{e}}$ \\
\cline { 2 - 4 } & 12 & $4,84^{\mathrm{b}}$ & $2,80^{\mathrm{a}}$ \\
\cline { 2 - 4 } & 24 & $4,69^{\mathrm{a}}$ & $4,50^{\mathrm{g}}$ \\
\hline \multirow{3}{*}{5} & 6 & $5,38^{\mathrm{c}}$ & $4,27^{\mathrm{f}}$ \\
\cline { 2 - 4 } & 12 & $4,73^{\mathrm{b}}$ & $3,10^{\mathrm{b}}$ \\
\cline { 2 - 4 } & 24 & $4,65^{\mathrm{b}}$ & $3,70^{\mathrm{c}}$ \\
\hline \multirow{3}{*}{7} & 6 & $5,44^{\mathrm{c}}$ & $3,87^{\mathrm{d}}$ \\
\cline { 2 - 4 } & 12 & $4,84^{\mathrm{b}}$ & $3,07^{\mathrm{b}}$ \\
\cline { 2 - 4 } & 24 & $4,39^{\mathrm{a}}$ & $3,56^{\mathrm{c}}$ \\
\hline
\end{tabular}

Superskrip yang sama menunjukkan tidak beda nyata pada $\alpha=$ 0,05

\section{Konsistensi}

Hasil analisa ragam menunjukkan bahwa semakin tinggi jumlah kultur dan semakin lama waktu fermentasi akan berpengaruh nyata $(\mathrm{P}<0,05)$ terhadap konsistensi Yogurt dengan kekentalan tertinggi yaitu pada jumlah kultur 3\% dengan waktu fermentasi 12 jam dengan jarak tempuh terpendek yaitu $2,80 \mathrm{~cm}$. Sedangkan yogurt yang paling encer adalah pada perlakuan jumlah kultur $3 \%$ dan waktu fermentasi 12 jam (Tabel 1).

Protein pada edamame akan membentuk gel saat dipanaskan hingga suhu $80^{\circ} \mathrm{C}$. Gel tersebut memiliki tekstur yang semi padat dan meningkatkan kekentalan pada yogurt. Kondisi inilah yang mempengaruhi kekentalan pada yogurt (Purbasari dkk, 2014). Namun, pada semua perlakuan dapat dilihat bahwa pada waktu fermentasi 12 jam menghasilkan yogurt dengan kekentalan paling tinggi. Hal ini berkaitan dengan titik isoelektrik protein, diduga $\mathrm{pH}$ 4,73-4,84 merupakan titik isoelektrik pada protein edamame. Pada titik tersebut protein akan mengalami penurunan kelarutan protein sehingga membentuk agregat protein.

\section{Uji Kesukaan}

Organoleptik merupakan parameter penting pada bahan pangan yang terkait dengan indra manusia sebagai penentu pengukuran daya terima suatu produk. Pada umumnya uji organoleptik menggunakan parameter warna, aroma, rasa dan tekstur. Hal ini penting dilakukan karena suatu produk tidak hanya mampu meningkatkan 
kesehatan manusia namun harus diterima dari segi organoleptinyaa. Hasil uji organoleptik pada yogurt edamame disajikan pada Tabel 3.

Hasil analisa ragam menunjukkan bahwa semakin tinggi jumlah starter dan semakin lama waktu fermentasi berpengaruh nyata $(\mathrm{P}<0,05)$ terhadap aroma, rasa dan tekstur dan tidak berpengaruh nyata $(\mathrm{P}>0,05)$ terhadap warna. Proses fermentasi pada sari edamame akan menyebabkan perubahan citarasa, aroma, warna dan tekstur dari sari edamame. Namun nilai kesukaan pada yogurt edamame ini masih perlu ditingkatkan dengan penambahan citarasa perisa jambu air (Purbasari dkk, 2014) dan belimbing (Jannah dkk, 2014) dapat meningkatkan kesukaan panelis pada yogurt.

Tabel 3. Hasil Uji Kesukaan Yogurt Edamame

\begin{tabular}{|c|c|c|c|c|c|}
\hline \multicolumn{2}{|c|}{ Perlakuan } & \multirow[b]{2}{*}{$\begin{array}{c}\text { War } \\
\text { na }\end{array}$} & \multirow[b]{2}{*}{$\begin{array}{c}\text { Arom } \\
\mathbf{a}\end{array}$} & \multirow[b]{2}{*}{ Rasa } & \multirow[b]{2}{*}{$\begin{array}{c}\text { Tekstu } \\
\mathbf{r}\end{array}$} \\
\hline $\begin{array}{c}\text { Jumlah } \\
\text { starter } \\
(\%)\end{array}$ & $\begin{array}{c}\text { Waktu } \\
\text { fermenta } \\
\text { si (jam) }\end{array}$ & & & & \\
\hline \multirow{3}{*}{3} & 6 & 2,90 & $2,12^{\mathrm{a}}$ & $\underset{c}{2,08^{a b}}$ & $2,08^{\mathrm{a}}$ \\
\hline & 12 & 3,20 & $1,96^{\mathrm{a}}$ & $1,56^{\mathrm{a}}$ & $2,04^{\mathrm{a}}$ \\
\hline & 24 & 3,56 & $1,80^{\mathrm{a}}$ & $1,88^{\mathrm{a}}$ & $2,96^{\mathrm{b}}$ \\
\hline \multirow{3}{*}{5} & 6 & 3,28 & $3,16^{\mathrm{b}}$ & $1,92^{\mathrm{ab}}$ & $2,96^{\mathrm{b}}$ \\
\hline & 12 & 3,36 & $2,88^{b}$ & $2,00^{\mathrm{ab}}$ & $2,44^{\mathrm{ab}}$ \\
\hline & 24 & 3,16 & $3,00^{\mathrm{b}}$ & $2,12^{\mathrm{ab}}$ & $2,88^{b}$ \\
\hline \multirow{3}{*}{7} & 6 & 3,28 & $2,92^{\mathrm{b}}$ & $2,00^{\mathrm{ab}}$ & $3,00^{\mathrm{b}}$ \\
\hline & 12 & 3,44 & $3,04^{\mathrm{b}}$ & $2,56^{\text {bc }}$ & $2,84^{\mathrm{b}}$ \\
\hline & 24 & 3,04 & $3,12^{\mathrm{b}}$ & $2,64^{b c}$ & $2,88^{b}$ \\
\hline
\end{tabular}

Superskrip yang sama menunjukkan tidak beda nyata pada $\alpha=$ 0,05

\section{Uji Mutu Hedonik}

Uji mutu hedonik merupakan uji yang spesifik untuk suatu jenis mutu tertentu. Tujuan dari uji mutu hedonic adalah untuk mengetahui respon terhadap sifat-sifat produk yang lebih spesifik, misalnya rasa buah dalam permen, sifat rasa gurih pada biscuit dan lain-lain. Hasil uji mutu hedonic pada yogurt edamame dapat dilihat pada Tabel 4.

Hasil analisa ragam menunjukkan semakin tinggi jumlah starter yang digunakan dan semakin lama waktu fermentasi berpengaruh nyata $(\mathrm{P}<0,05)$ terhadap mutu hedonic warna, aroma dan rasa namun tidak berbeda nyata $(\mathrm{P}>0,05)$ terhadap tekstur. Proses fermentasi akan menyebabkan warna hijau yang semakin memudar menjadi agak hijau (3,32-2,32). Hal ini sesuai dengan penelitian Kartikasari dan Nisa (2014) yang menyebutkan bahwa semakin lama fermentasi makan tingkat kecerahan dari yogurt akan semakin meningkat. Komponen warna dari edamame akan terhidrolisis sehingga menghasilkan warna yang semakin cerah.
Tabel 4. Hasil Mutu Hedonik Yogurt Edamame

\begin{tabular}{|c|c|c|c|c|c|}
\hline \multicolumn{2}{|c|}{ Perlakuan } & \multirow[b]{2}{*}{ Warna } & \multirow[b]{2}{*}{ Aroma } & \multirow[b]{2}{*}{ Rasa } & \multirow[b]{2}{*}{ Tekstur } \\
\hline $\begin{array}{c}\text { Jumlah } \\
\text { starter } \\
(\%)\end{array}$ & $\begin{array}{c}\text { Waktu } \\
\text { fermentasi } \\
\text { (jam) }\end{array}$ & & & & \\
\hline \multirow{3}{*}{3} & 6 & $3,32^{\mathrm{d}}$ & $2,64^{\mathrm{a}}$ & $2,24^{\mathrm{a}}$ & 3,64 \\
\hline & 12 & $3,20^{\mathrm{cd}}$ & $2,72^{\mathrm{b}}$ & $2,28 \mathrm{a}$ & 3,68 \\
\hline & 24 & $3,24^{\mathrm{cd}}$ & $2,72^{\mathrm{c}}$ & $2,60^{\mathrm{bc}}$ & 3,72 \\
\hline \multirow{3}{*}{5} & 6 & $3,32^{\mathrm{d}}$ & $2,92^{\mathrm{ab}}$ & $2,44^{\text {bc }}$ & 3,76 \\
\hline & 12 & $2,92^{\text {bcd }}$ & $3,00^{\mathrm{abc}}$ & $2,56^{\mathrm{bc}}$ & 3,80 \\
\hline & 24 & $2,72^{\mathrm{abc}}$ & $3,12^{\text {cd }}$ & $2,84^{\mathrm{cd}}$ & 3,96 \\
\hline \multirow{3}{*}{7} & 6 & $2,64^{\mathrm{ab}}$ & $3,16^{\text {cd }}$ & $2,60^{\mathrm{bc}}$ & 3,93 \\
\hline & 12 & $2,52^{\mathrm{ab}}$ & $3,20^{\text {cd }}$ & $2,88^{\mathrm{cd}}$ & 4,04 \\
\hline & 24 & $2,32^{\mathrm{a}}$ & $3,32^{\mathrm{d}}$ & $3,24^{\mathrm{d}}$ & 4,24 \\
\hline
\end{tabular}

Superskrip yang sama menunjukkan tidak beda nyata pada $\alpha=$ 0,05

Aroma dan rasa pada yogurt edamame semakin asam sebanding dengan peningkatan jumlah starter yang digunakan dan semakin lama waktu fermentasi yaitu berkisar antara 2,64-3,32 (agak asam-asam) untuk aroma dan 2,24-3,24 (agak asam-asam) untuk rasa. Aroma dan rasa yogurt dipengaruhi oleh senyawa asetaldehida, diasetil, asam asetat, asam laktat dan asam lain hasil fermentasi bakteri asam laktat (Askar dan Sugiarto, 2005). Menurut Jannah dkk (2014) Lactobacillus bulgaricus lebih berperan pada pembentukan aroma sedangkan Streptococcus thermophillus lebih berperan pada pembentukan rasa yogurt.

Semakin tinggi jumlah starter yang digunakan dan semakin lama waktu fermentasi akan meningkatkan kekentalan pada yogurt dengan nilai 3,64-4,24 (agak kental-kental). Protein pada edamame akan membentuk gel saat dipanaskan hingga suhu $80^{\circ} \mathrm{C}$. Gel tersebut memiliki tekstur yang semi padat dan meningkatkan kekentalan pada yogurt. Selain itu $\mathrm{pH}$ yang semakin menurun pada tiap perlakuan akan menurunkan kelarutan protein sehingga membentuk agregat protein. Kondisi inilah yang mempengaruhi kekentalan pada yogurt (Purbasari dkk, 2014).

\section{Perlakuan Terbaik}

Berdasarkan pH, konsistensi dan uji organoleptic didapatkan perlakuan terbaik yogurt pada perlakuan jumlah kultur $7 \%$ dan waktu fermentasi 24 jam. Adapun karakteristik yogurt edamame tersebut adalah Perlakuan terbaik pada jumlah kultur $7 \%$ dan waktu fermentasi 24 jam dengan karakteristik pH 4,39, konsistensi 3,56 cm, kesukaan warna, aroma, rasa dan tekstur netral. Sedangkan pada mutu hedonic warna agak hijau, aroma dan rasa asam, tekstur kental.

Perlakuan terbaik dilakukan uji lanjut yaitu aktivitas antioksidan. Berdasarkan hasil analisa 
Nita Maria Rosiana, Dahlia Indah Amareta, Karakteristik Yogurt Edamame Hasil Fermentasi Kultur Campuran Bakteri Asam Laktat Komersial Sebagai Pangan Fungsional Berbasis Biji-Bijian

didapatkan aktivitas antioksidan pada yogurt edamame $19,18 \%$, meningkat dari sari edamame yang memiliki aktivitas antioksidan sebanyak 16,25\%. Aktivitas antioksidan ini masih lebih rendah dibandingkan yogurt susu sapi dengan penambahan sari sirsak yaitu sebesar $61,503 \%$ (Kartikasari dan Nisa, 2014).

Salah satu hasil metabolit pada yogurt adalah peptide bioaktif yang memiliki sifat antioksidan. Selain itu fenol dan isoflavon pada edamame juga merupakan jenis antioksidan yang terdapat pada yogurt edamame. Antioksidan merupakan suatu senyawa yang berfungsi untuk melindungi sel dari efek berbahaya radikal bebas oksigen yang berasal dari metabolisme tubuh maupun faktor eksternal lainnya. Senyawa antioksidan memiliki peran yang sangat penting dalam kesehatan. Berbagai bukti ilmiah menunjukkan bahwa senyawa antioksidan mengurangi resiko terhadap penyakit kronis seperti kanker dan penyakit jantung koroner (Amrun et al., 2007). Keberadaan antioksidan pada yogurt edamame menjadikan yogurt ini menjadi salah satu sumber pangan fungsional.

\section{KESIMPULAN}

Yogurt perlakuan terbaik adalah yogurt yang dibuat dengan jumlah kultur $7 \%$ dan waktu fermentasi 24 jam pada suhu ruang. Karakteristik yogurt edamame tersebut adalah $\mathrm{pH}$ 4,39, konsistensi 3,56 cm, kesukaan warna, aroma, rasa dan tekstur netral. Sedangkan pada mutu hedonic warna agak hijau, aroma dan rasa asam, tekstur kental dan aktivitas antioksidan 19,18\%.

\section{UCAPAN TERIMAKASIH}

Terimakasih penulis ucapkan kepada P3M Politeknik Negeri Jember atas dukungan dana yang digunakan dalam penelitian ini.

\section{DAFTAR PUSTAKA}

Amrun, H.M, Umiyah, \& Evi Umayah U, 2007. Uji Aktifitas Antioksidan Ektrak Air dan Ektrak Metanol Beberapa Varian Buah Kenitu (Chrysophyllum cainito L) dari daerah Jember, Berk. Penel. Hayati, 13 : 45-50.

Askar, S. dan Sugiarto, 2005. Uji Kimiawi dan Organoleptik sebagai Uji Mutu Yogurt. Prosiding Temu Teknis Nasioanl Tenaga Fungsional Pertanian

Fatmawati, U., Prasetyo, F.I., Supia, M.. Utami, A.N. 2013. Karakteristik Yogurt yang Terbuat dari Berbagai Jenis Susu dengan Penambahan Kultur Campuran Lactobacillus bulgaricus dan Streptococcus thermophillus. Bioedukasi Vol 6 No 2
Fitriyana, N.I. 2014. Pengembangan Pangan Fungsional Antikolesterol Dari Kedelai Edamame (Glycine Max (L) Merril). Http://Repository.Unej.Ac.Id/Bitstream/Hand le/123456789/64231/Nurul\%20isnaini\%20fit riyana_Pemula 182.Pdf?Sequence $=1$ Diakses 17 Agustus 2016

Jannah, A.M., Legowo, A.M., Pramono, Y.B., AlBarri, A.N., Abduh, S.B.M.A., 2014. Total Bakteri Asam Laktat, pH, Keasaman, Citarasa dan Kesukaan Yogurt Drink dengan Penambahan Ekstrak Buah Belimbing. Jurnal Aplikasi Teknologi 3 (2) 2014

Kartikasari, D.I., Nisa, F.C. 2014. Pengaruh Penambahan Sari Buah Sirsak dan Lama Fermentasi terhadap Karakteristik Fisik dan Kimia Yogurt. Jurnal Pangan dan Agroindustri Vol. 2 No 4 p.239-248

Prasetyo, H. 2010. Pengaruh Penggunaan Starter Yogurt pada Level Tertentu terhadap Karakteristik Yogurt yang Dihasilkan. Skripsi Fakultas Pertanian Universitas Sebelas Maret. Solo

Purbasari, A., Pramono, Y.B., dan Abduh, S., B., M., 2014. Nilai pH, Kekentalan, Citarasa Asam dan Kesukaan pada Susu Fermentasi dengan Perisa Alami Jambu Air. Jurnal Aplikasi Teknologi Pangan 3 (4)

Samruan, W., R. Oonsivilai, dan A. Oonsivilai. 2012. Soybean and Fermented Soybean Extract Antioxidant Activity. World Academy of Science, Engineering and Technology, Suranaree University of Technology, Thailand.

Wahyuhapsari, R., Wardani, A.K. 2013. Pembuatan Miso Dengan Memanfaatkan Edamame (Kajian Konsentrasi Koji Dan Suhu Inkubasi). Jurnal Pangan dan Agroindustri Vol. 1 No.1 p.157-167

Zakaria, Y. 2008. Sifat Kimia, Mikrobiologi dan Organoleptik Yogurt yang Menggunakan Presentase Lactobacillus casei dan Kadar Gula yang Berbeda. Agripet Vol 8 No 1 